\title{
Implementation of interactive conceptual instruction (ICI) with computer simulation: impact of students' misconceptions on momentum and impulse material
}

\author{
Ida Kaniawati' ${ }^{1}$ Grace Triyani², Agus Danawan ${ }^{3}$, Iyon Suyana ${ }^{4}$, Achmad Samsudin ${ }^{5}$, Endi Suhendi ${ }^{6 *}$ \\ ${ }^{1-6}$ Physics Education Department, Universitas Pendidikan Indonesia, Jl. Dr. Setiabudhi No. 229 Bandung 40154, Indonesia
}

*Corresponding Address: endis@upi.edu

\begin{tabular}{|c|c|}
\hline Article Info & ABSTRACT \\
\hline $\begin{array}{l}\text { Article history: } \\
\text { Received: January } 15^{\text {th }}, 2021 \\
\text { Accepted: April } 24^{\text {th }}, 2021 \\
\text { Published: April } 30^{\text {th }}, 2021\end{array}$ & $\begin{array}{l}\text { Misconceptions frequently occur in various physics concepts, including } \\
\text { momentum and impulse. Misconceptions in students must be addressed } \\
\text { since they can hinder the learning process. This study aimed at investigating } \\
\text { students' misconceptions on momentum and impulse material after } \\
\text { implementing Interactive Conceptual Instruction (ICI) with computer } \\
\text { simulations. The method employed in this study was a quasi-experimental }\end{array}$ \\
\hline $\begin{array}{l}\text { Keywords: } \\
\text { Misconception; } \\
\text { Interactive Conceptual } \\
\text { Instruction; } \\
\text { Computer Simulation; } \\
\text { Momentum and Impulse. }\end{array}$ & $\begin{array}{l}\text { design with One Group Pretest-Posttest Design. This research was } \\
\text { conducted on } 30 \text { students of the tenth grade determined by the purposive } \\
\text { sampling technique. Fifteen four-tier test items were used as the research } \\
\text { instrument. The N-gain analysis was performed to know the reduction of } \\
\text { misconceptions. The results showed that the N-gain value obtained was } 0.46 \\
\text { with moderate interpretation, meaning that Interactive Conceptual } \\
\text { Instruction (ICI) aided with computer simulations could reduce student } \\
\text { misconceptions. The results also indicated that the misconception after } \\
\text { treatment was smaller than before treatment. This phenomenon can be seen } \\
\text { from the reduction of misconceptions by } 11.6 \% \text { after implementing } \\
\text { Interactive Conceptual Instruction (ICI) with computer simulations. } \\
\text { Therefore, it can be concluded that Interactive Conceptual Instruction (ICI) } \\
\text { with computer simulations can facilitate students in the learning process so } \\
\text { that misconceptions can be reduced. }\end{array}$ \\
\hline
\end{tabular}

\section{INTRODUCTION}

Physics learning and understanding the concepts are two things that cannot be separated. In a learning process, there are often gaps among students in understanding the concepts because they usually have insight from daily experiences and information from the surrounding environment, which is called the student's prior knowledge (Kaniawati et al., 2019; Samsudin et al., 2018; Tompo et al., 2016). Often the prior knowledge that students have does not match the concepts possessed by physicists. In Physical Science, the right concept refers to the conception of physics scientists (Adimayuda et al., 2020; Aminudin et al., 2019; Fratiwi et al., 2020).
The different concepts that students and physicists have been known as misconceptions. The occurrence of misconceptions can be caused by several sources, namely students, teachers, textbooks used, context, and teaching methods (Irwansyah et al., 2018; Soeharto et al., 2019; Tumanggor et al., 2020).

The goal of learning physics is to be able to master physics concepts well. Based on this, it is hoped that misconceptions will not happen. To achieve these goals, the teacher must build ideal learning that can help students master physics concepts. One of the characteristics of ideal learning that follows the development of the world of education is learning that makes students more active in 
the classroom. Teacher-centered learning patterns have now changed to studentcentered learning patterns (Amelia et al., 2020; Rismawati et al., 2019; Santoso et al., 2018). This means that students are expected to play a more active role while the teacher only acts as a facilitator. The learning pattern used is still teacher-centered without demonstrating the phenomenon or its application in everyday life. As a result, student learning outcomes are not optimal. This can also lead to misconceptions.

The misconception is one of the most common problems in the physics learning process (Kaniawati et al., 2019; Kurniawan et al., 2019; Zulfikar et al., 2019). Many students experience misconceptions in physics concepts, one of which is in the momentum and impulse lesson unit. This is because momentum and impulse in everyday life are difficult to observe since they tend to be abstract. This abstractness is due to the ideal phenomenon of momentum and impulse that cannot be found in everyday life. Whereas in learning, ideal conditions must be the basis for studying a phenomenon. Thus, potential misconceptions can occur and hinder the physics learning process because the concepts in physics are interrelated (Fratiwi et al., 2020; Nasrudin \& Azizah, 2020; Samsudin et al., 2020). When a misconception occurs, it will hinder the process of understanding the next concept. Thus, the misconception must be immediately resolved. Effective and efficient learning solutions are needed to reduce misconceptions (Akmam et al., 2018; Astiti et al., 2020; Ling, 2017). One of them is using the Interactive Conceptual Instruction (ICI) learning model and using learning media.

Interactive Conceptual Instruction (ICI) is a learning approach designed to focus on cultivating concepts among students (Samsudin et al., 2016). Previous research has shown that Interactive Conceptual Instructions (ICI) can improve students' conceptual understanding (Patriot et al.,
2017; Samsudin et al., 2017). This means that students' misconceptions can be reduced. Interactive Conceptual Instruction (ICI) has 4 phases: conceptual focus, text, research-based material, and classroom interaction.

Learning media are usually used to demonstrate physical phenomena. However, the learning media that are often used today have limitations. They cannot demonstrate physical phenomena that are abstract or difficult to bring into the classroom. To overcome these limitations, currently, there have been many computer simulation-based visual media. Computer simulations can help students understand abstract concepts (Widyawati, 2019). This was also stated by several researchers who explained that computer simulations could be used for abstract physics concepts (Amalia et al., 2019; Fratiwi et al., 2018; Kaniawati et al., 2016).

Then, the purpose of this study was to determine students' misconceptions after implementing Interactive Conceptual Instruction (ICI) with computer simulations on momentum and impulse material. The difference with previous research is due to the help of computer simulations on Interactive Conceptual Instruction (ICI), especially the simulations used focus on momentum and impulses.

\section{METHODS}

The method used in this study was quasiexperimental with one group pretest-posttest design. Quasi-experimental is employed because, in reality, it is difficult to get a control group to use for research (Amelia et al., 2020; Creswell, 2014; Gersten et al., 2005; Rogers \& Révész, 2020). The reason researchers use quasi-experimental because they cannot control external variables that can affect the experiment, for example, the background of parents, economic conditions, residence, and other factors related to the study sample so that control is carried out only by providing treatments in school. One-group pretest-posttest design is 
a quasi-experiment where a group is measured and observed before and after the treatment is given, as shown in Figure 1.

\begin{tabular}{|c|c|c|}
\hline $\mathrm{O}_{1}$ & $\mathrm{X}$ & $\mathrm{O}_{2}$ \\
Pre-test & Treatment & Post-test \\
\hline
\end{tabular}

Figure 1. One-group Pretest-Posttest Design

\section{Research Participants and Instruments}

The population of this study was all students of grade $\mathrm{X}$ majoring in Sciences (MIPA) in one high school in Bandung. In this study, however, not all populations were used as research subjects. The researcher only used one class as the research sample. The research sample was one class from grade X MIPA consisted of 30 students. In determining the sample, a purposive sampling technique was used in which the research subjects were selected based on certain objectives.One of them is based on a recommendation from the teacher because the researcher asked a class that had not been taught the concepts of momentum and impulse.

The instrument used in this study was a diagnostic test. Diagnostic tests were utilized to identify student misconceptions. This diagnostic test consisted of 15 items in the form of a four-tier test having four levels of characteristics. The first level was a multiple choice which contained knowledge questions. The second level contained questions about students 'beliefs about the answers chosen at the first level.

In contrast, the third level contained multiple choices about why students chose the answer at the first level. The fourth level contained questions about students' beliefs about the answers chosen in the third level. The following was an example of a four-tier test instrument presented in Figure 2.

9.1 Look at the three phenomena below!

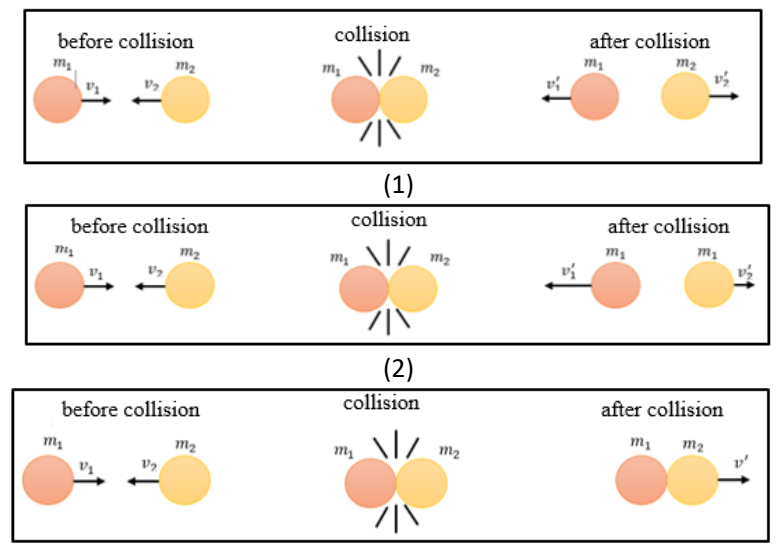

(3)

Based on the three phenomena above, the law of momentum conservation applies to which number?

a. (1)

b. (2)

c. (3)

d. (1) and (2)

e. (1), (2), and (3)

9.2 Your confidence level in answering question number 9.1:
a. Sure
b. Not Sure

9.3 Your reason for answering question number 9.1:

a. The law of momentum conservation only applies to a perfectly elastic collision.

b. The law of momentum conservation only applies to the partially elastic collision.

c. The law of momentum conservation only applies to an inelastic collision.

d. The law of momentum conservation applies to perfectly elastic collision, partially elastic collision, and inelastic collision.

e.

9.4 Your confidence level in choosing the reason for question number 9.1:

a. Sure

b. Not sure

Figure 2. One of the Examples of Four-Tier Test Instrument 
Figure 2 showing an example of question number 9 in a four-tier diagnostic test on momentum and impulse material. It was a multiple choice with four cheaters and one correct answer that the student must choose at the first level. The second level was the level of confidence for the answers at the first level, offering options "Sure" and "Not Sure." The third level was a choice of reasons (multiple choice) for reasons at the first level, in the form of four reasons that had been provided and one open answer. The fourth level was the level of confidence for the answers at the third level in the form of two choices, "Sure" and "Not Sure."

\section{Research Design}

The research design used was the One Group Pretest-Posttest Design. In this study, the research subject was only one experimental class that was given treatment. The given treatment was the application of Interactive Conceptual Instruction (ICI) with computer simulations. The pretest was given when students had not received treatment intending to know the students' misconceptions before being given treatment. After the treatment, the students were given a posttest to determine students' misconceptions after implementing Interactive Conceptual Instruction (ICI) with computer simulations.

\section{Interactive Conceptual Instruction (ICI) with Computer Simulations}

Interactive Conceptual Instruction (ICI) was developed by Savinainen \& Scott (2002). It is an approach developed to improve students' conceptual understanding. The main component of ICI is to focus on concepts, use of text, research-based materials, and class interactions in Figure 3.

The first stage begins with showing demonstrations, operating computer multimedia such as simulations or videos that show physical phenomena related to the concepts to be discussed. Demonstrations, simulations, or videos are useful as objects of observation and discussion that serve as an introduction to which the teacher uses in instilling concepts.

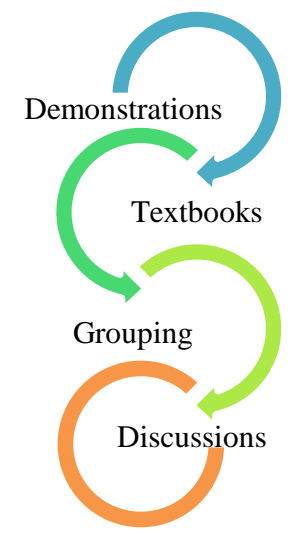

Figure 3. The Stage of Interactive Conceptual Instruction (ICI)

Students are allowed to find important information related to the concept being discussed through textbooks in the second stage. Textbooks are used to find keywords related to concepts. Then students are allowed to make concept maps based on information or keywords that have been obtained through reading textbooks. According to Novak and Gowin (Savinainen $\&$ Scott, 2002), the mind map enables students to see the big picture and see the key relationships of a concept.

In the third stage, students are asked to make groups of three or four students. Then students are allowed to conduct experiments based on student worksheets and analyze the experimental results.

In the fourth stage in Interactive Conceptual Instruction (ICI), class interaction in discussions between students and interactions between teachers and students is conducted. The teacher guides each group's discussion and helps students solve problems by comparing the results of student worksheets for each group. In this study, computer simulations of impulse and momentum utilized like in Figures 4 and 5 showings demonstrated an example of computer simulation. 


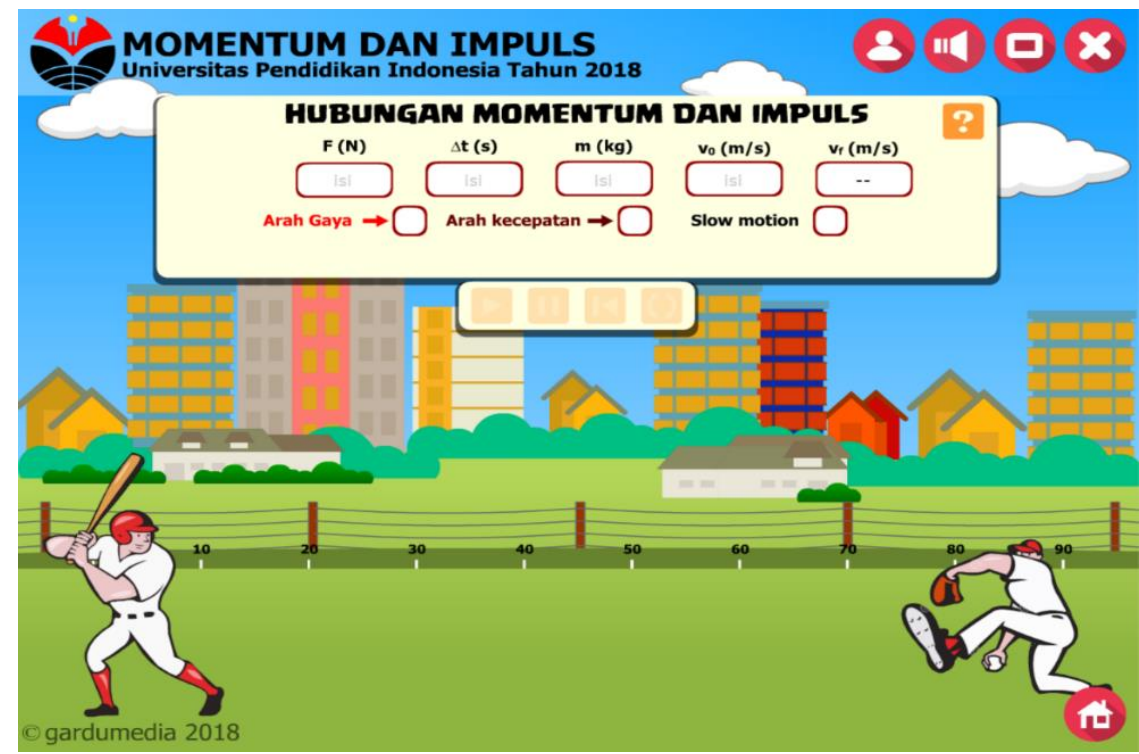

Figure 4. A Simulation Display of Momentum and Impulse Relationship

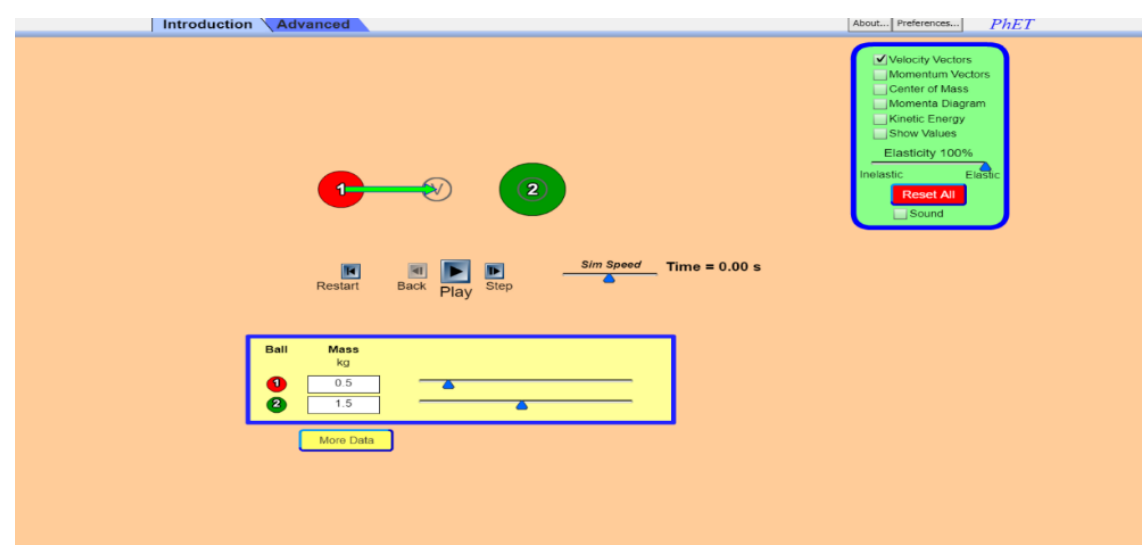

Figure 5. A Simulation Display of Collision

\section{Data Analysis}

It is necessary to analyze the combination of students' answers to find out student misconceptions. The results of the combination of student answers were grouped into five categories, namely misconceptions, understanding concepts, partially understanding, not understanding concepts, and cannot be coded as shown in Table 1 (Samsudin et al., 2017).

Table 1. Students' Misconception Criteria

\begin{tabular}{ccccc}
\hline Conception Criteria & Tier 1 & Tier 2 & Tier 3 & Tier 4 \\
\hline Mis-conception (MC) & Incorrect & Sure & Incorrect & Sure \\
\hline Sound Understanding (SU) & Correct & Sure & Correct & Sure \\
\hline Partial Understanding (PU) & Correct & Not sure & Correct & Not sure \\
\cline { 2 - 5 } & Correct & Sure & Correct & Not sure \\
\cline { 2 - 5 } & Correct & Not sure & Correct & Sure \\
\cline { 2 - 5 } & Correct & Not sure & Incorrect & Not sure \\
\cline { 2 - 5 } & Incorrect & Not sure & Correct & Not sure \\
\cline { 2 - 5 } & Correct & Sure & Incorrect & Not sure \\
\cline { 2 - 5 } & Correct & Not sure & Incorrect & Sure \\
\cline { 2 - 4 } & Incorrect & Sure & Correct & Not sure
\end{tabular}




\begin{tabular}{|c|c|c|c|c|}
\hline Conception Criteria & Tier 1 & Tier 2 & Tier 3 & Tier 4 \\
\hline & Incorrect & Not sure & Correct & Sure \\
\hline & Correct & Sure & Incorrect & Sure \\
\hline & Incorrect & Sure & Correct & Sure \\
\hline \multirow[t]{3}{*}{ No Understanding (NU) } & Incorrect & Not sure & Incorrect & Not Sure \\
\hline & Incorrect & Sure & Incorrect & Not sure \\
\hline & Incorrect & Not sure & Incorrect & Sure \\
\hline
\end{tabular}

Equation 1 is used to calculate the percentage of student categories (Samsudin et al., 2021).

$$
C C(\%)=\frac{\sum \text { conception criteria }}{\sum \text { total students }} \times 100 \%
$$

Note: $C C=$ Conception criteria

Changes in student misconceptions after implementing Interactive Conceptual Instruction (ICI) with computer simulations can be identified using the N-gain equation. The $\mathrm{N}$-gain is a measure of increasing student understanding, calculated from the difference in the number of students who experience changes from not understanding or misconceptions to understanding concepts (Hikmat et al., 2014). In this study, the $\mathrm{N}$-gain used was the $\mathrm{N}$-gain adopted from Hake (1998) but was redeveloped by Hikmat et al. (2014) to identify a decrease in the number of students experiencing misconceptions. The N-gain can be formulated as follows.

$$
N \text { gain }=\frac{\% M_{\text {pre }}-\% M_{\text {post }}}{\% M_{\text {pre }}-\% M_{\text {ideal }}}
$$

Knowing that the Interactive Conceptual Instruction (ICI) learning model with computer simulations can change students' misconceptions on momentum and impulse material, further analysis was carried out to see how the types of misconceptions change that occurs in students. The type of change in student misconceptions was depicted in Table 2.

Table 2. Type of Change in Students' Misconception

\begin{tabular}{cc}
\hline Type of Change & Category \\
\hline Positive $(+)$ & Students experience a decrease in misconceptions \\
\hline Negative $(-)$ & Students experience an increase in misconceptions. \\
\hline No change $(0)$ & Students do not experience changes in misconceptions. \\
\hline
\end{tabular}

Furthermore, changing students' conceptions need to be analyzed to find out whether or not students experience changes in conceptions. Changes in conception can be seen based on the results of the pretest and posttest. In this study, the changes in analyzed conceptions were only changes in misconceptions. Changes in conceptions were shown in Table 3 (Samsudin et al., 2016).

Table 3. Categories of Students' Conception Changes

\begin{tabular}{cccc}
\hline $\begin{array}{c}\text { Conception during } \\
\text { Pretest }\end{array}$ & $\begin{array}{c}\text { Change } \\
(\rightarrow)\end{array}$ & $\begin{array}{c}\text { Conception during } \\
\text { Post-test }\end{array}$ & Category of Change \\
\hline $\mathrm{MC}$ & $\rightarrow$ & $\mathrm{MC}$ & \multirow{2}{*}{ Acceptable Change (AC) } \\
\hline $\mathrm{MC}$ & $\rightarrow$ & $\mathrm{MC}$ & \\
\hline $\mathrm{NU}$ & $\rightarrow$ & $\mathrm{NU}$ & \\
\hline $\mathrm{NU}$ & $\rightarrow$ & $\mathrm{NU}$ & \\
\hline $\mathrm{PU}$ & $\rightarrow$ & $\mathrm{PU}$ & \\
\hline $\mathrm{NC}$ & $\rightarrow$ & $\mathrm{NC}$ & \\
\hline
\end{tabular}




\begin{tabular}{cccc}
\hline $\begin{array}{c}\text { Conception during } \\
\text { Pretest }\end{array}$ & $\begin{array}{c}\text { Change } \\
(\rightarrow)\end{array}$ & $\begin{array}{c}\text { Conception during } \\
\text { Post-test }\end{array}$ & Category of Change \\
\hline $\mathrm{MC}$ & $\rightarrow$ & $\mathrm{NU}$ & \\
\hline $\mathrm{NU}$ & $\rightarrow$ & $\mathrm{MC}$ & \\
\hline $\mathrm{PU}$ & $\rightarrow$ & $\mathrm{MC}$ & \\
\hline $\mathrm{PU}$ & $\rightarrow$ & $\mathrm{NU}$ & \\
\hline $\mathrm{SU}$ & $\rightarrow$ & $\mathrm{PU}$ & \\
\hline $\mathrm{SU}$ & $\rightarrow$ & $\mathrm{NU}$ & \\
\hline $\mathrm{SU}$ & $\rightarrow$ & $\mathrm{MC}$ & \\
\hline $\mathrm{PU}$ & $\rightarrow$ & $\mathrm{NC}$ & \\
\hline $\mathrm{MC}$ & $\rightarrow$ & $\mathrm{NC}$ & No Change $(\mathrm{NCh})$ \\
\hline $\mathrm{NC}$ & $\rightarrow$ & $\mathrm{MC}$ & \\
\hline $\mathrm{NU}$ & $\rightarrow$ & $\mathrm{NC}$ & \\
\hline $\mathrm{NC}$ & $\rightarrow$ & $\mathrm{NU}$ & \\
\hline $\mathrm{PU}$ & $\rightarrow$ & $\mathrm{PU}$ & \\
\hline $\mathrm{NU}$ & $\rightarrow$ & $\mathrm{NU}$ & \\
\hline $\mathrm{MC}$ & $\rightarrow$ & $\mathrm{MC}$ & \\
\hline $\mathrm{SU}$ & $\rightarrow$ & $\mathrm{SU}$ & \\
\hline $\mathrm{NC}$ & $\rightarrow$ & $\mathrm{NC}$ &
\end{tabular}

\section{RESULTS AND DISCUSSION}

Before implementing Interactive Conceptual Instruction (ICI), the preconception profiles of students with computer simulations were obtained from the pretest results given before treatment. Based on the pretest results, the students 'conception profiles were obtained from students' answers, which were grouped into five categories: sound understanding, partial understanding, no understanding, misconception, and no coding. Students categorized as no coding were students who did not fill in one tier or more in one question. Figure 6 illustrated the general profile of students' conception before implementing Interactive Conceptual Instruction (ICI) learning with the help of computer simulations.

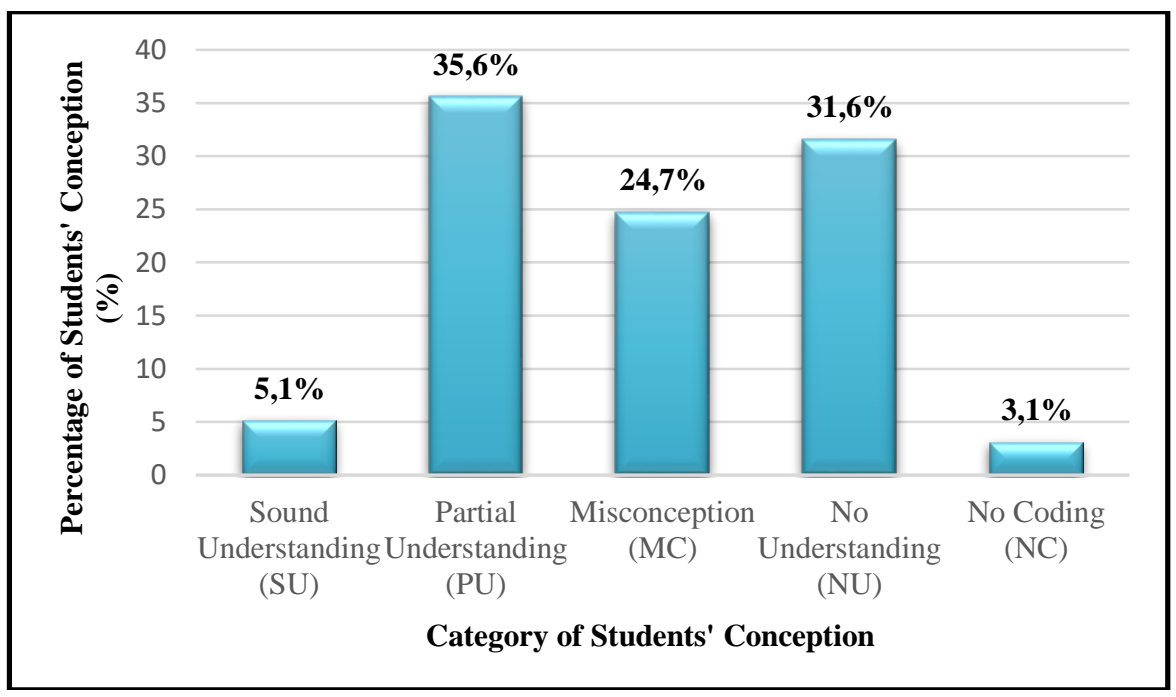

Figure 6. Conception profile Based on Pretest Results

Based on Figure 6, most students' understanding with a percentage of $35.6 \%$. conception category was partial Although understanding the concept is high, 
there were still misconceptions as many as $24.7 \%$.

Before implementing Interactive Conceptual Instruction (ICI), the preconception profiles of students with computer simulations were obtained from the post-test results given after treatment. Figure 7 shows students' general profile after implementing Interactive Conceptual Instruction (ICI) learning with computer simulations.

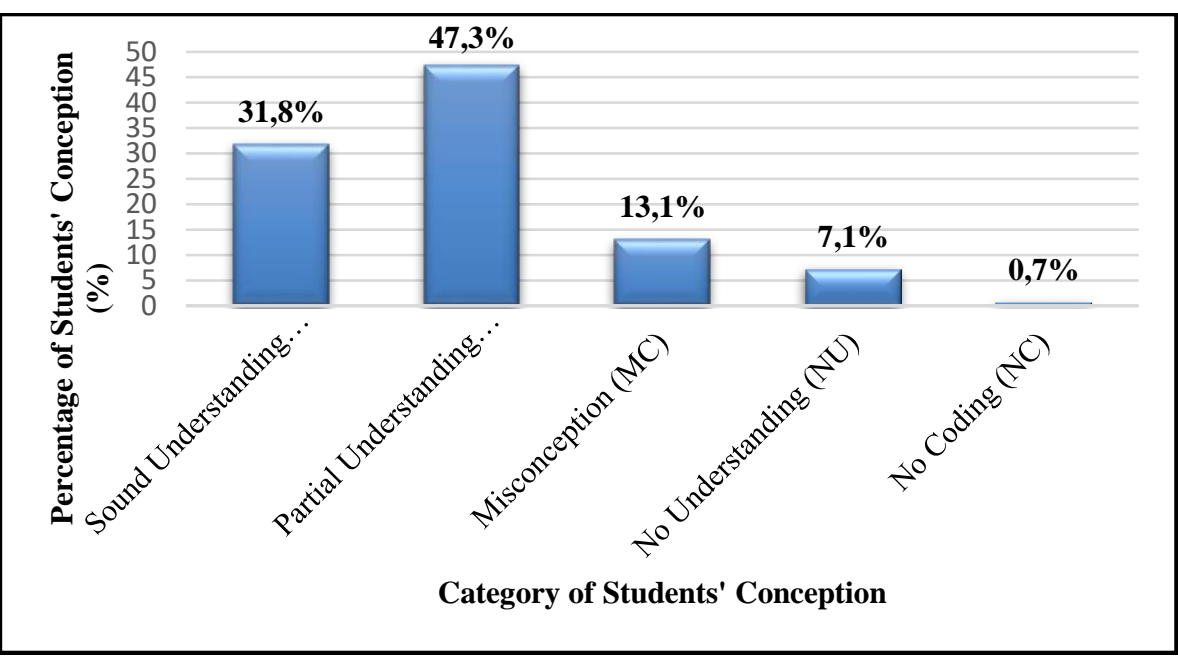

Figure 7. Conception Profile Based on Posttest Results

Based on Figure 7, the category of student conceptions was partial understanding or partial understanding, with a percentage of $47.3 \%$. Although the percentage of understanding the concept was big, there were still misconceptions as many as $13.1 \%$. Based on the research results that were carried out, the $\mathrm{N}$-gain was obtained, which was illustrated in Table 4.

Table4.The N-gain Score based on the Students' Pretest and Posttest Results

\begin{tabular}{|c|c|c|c|c|c|c|c|}
\hline \multirow[b]{2}{*}{ No. } & \multicolumn{2}{|l|}{ Pretest } & \multicolumn{2}{|l|}{ Post-test } & \multirow[b]{2}{*}{ \%Mpre - \%Mpost } & \multirow[b]{2}{*}{$\Delta \mathbf{M}$} & \multirow[b]{2}{*}{ Interpretation } \\
\hline & $\begin{array}{c}\text { Number of } \\
\text { students' } \\
\text { misconceptions }\end{array}$ & $\%$ & $\begin{array}{c}\text { Number of } \\
\text { students' } \\
\text { misconceptions }\end{array}$ & $\%$ & & & \\
\hline 1 & 6 & 20,0 & 1 & 3,3 & 16,7 & 0,83 & High \\
\hline 2 & 9 & 30,0 & 3 & 10,0 & 20,0 & 0,67 & Medium \\
\hline 3 & 7 & 23,3 & 3 & 10,0 & 13,3 & 0,57 & Medium \\
\hline 4 & 5 & 16,7 & 3 & 10,0 & 6,7 & 0,40 & Medium \\
\hline 5 & 5 & 16,7 & 3 & 10,0 & 6,7 & 0,40 & Medium \\
\hline 6 & 8 & 26,7 & 4 & 13,3 & 13,3 & 0,50 & Medium \\
\hline 7 & 9 & 30,0 & 5 & 16,7 & 13,3 & 0,44 & Medium \\
\hline 8 & 16 & 53,3 & 9 & 30,0 & 23,3 & 0,44 & Medium \\
\hline 9 & 10 & 33,3 & 4 & 13,3 & 20,0 & 0,60 & Medium \\
\hline 10 & 6 & 20,0 & 4 & 13,3 & 6,7 & 0,33 & Medium \\
\hline 11 & 4 & 13,3 & 3 & 10,0 & 3,3 & 0,25 & Low \\
\hline 12 & 6 & 20,0 & 6 & 20,0 & 0,0 & 0,00 & Low \\
\hline 13 & 6 & 20,0 & 2 & 6,7 & 13,3 & 0,67 & Medium \\
\hline 14 & 5 & 16,7 & 3 & 10,0 & 6,7 & 0,40 & Medium \\
\hline 15 & 9 & 30,0 & 6 & 20,0 & 10,0 & 0,33 & Medium \\
\hline & & & N-gain & & & 0,46 & Medium \\
\hline
\end{tabular}


Based on Table 4, it can be seen that the $\mathrm{N}$-gain calculation showed the result of 0.46 with a "Medium" interpretation. This indicated that the introduction of Interactive Conceptual Instruction (ICI) with computer simulations impacted changing students' misconceptions on momentum and impulse material. Following the results of previous research conducted by Achmad Samsudin et al. (2016), it showed that the multimediabased ICI learning model effectively increased the understanding of the concept of prospective physics teachers on electrical concepts. Misconceptions in the study were also reduced, indicated by the reduced percentage of student misconceptions from pretest to posttest.

Knowing that the Interactive Conceptual Instruction (ICI) learning model with computer simulations can change students' misconceptions on momentum and impulse material, further analysis was carried out to see how the types of misconceptions change that occurs in students. Table 5 showed the types of changes in student misconceptions based on Table 2 .

Table 5. Type of Students' Misconceptions Changes

\begin{tabular}{lllll}
\hline Item & $\begin{array}{l}\text { Prete } \\
\text { st } \\
(\boldsymbol{\%})\end{array}$ & $\begin{array}{l}\text { Post- } \\
\text { test } \\
(\boldsymbol{\%})\end{array}$ & $\begin{array}{l}\boldsymbol{C} \boldsymbol{C} \\
(\boldsymbol{\%})\end{array}$ & Type of Change \\
\hline 1 & 20 & 3,3 & 16,7 & Positive (+) \\
\hline 2 & 30 & 10 & 20,0 & Positive (+) \\
\hline 3 & 23,3 & 10 & 13,3 & Positive (+) \\
\hline 4 & 16,7 & 10 & 6,7 & Positive (+) \\
\hline 5 & 16,7 & 10 & 6,7 & Positive (+) \\
\hline 6 & 26,7 & 13,3 & 13,3 & Positive (+) \\
\hline 7 & 30 & 16,7 & 13,3 & Positive (+) \\
\hline 8 & 53,3 & 30 & 23,3 & Positive (+) \\
\hline 9 & 33,3 & 13,3 & 20,0 & Positive (+) \\
\hline 10 & 20 & 13,3 & 6,7 & Positive (+) \\
\hline 11 & 13,3 & 10 & 3,3 & Positive (+) \\
\hline 12 & 20 & 20 & 0,0 & No Change \\
\hline 13 & 20 & 6,7 & 13,3 & Positive (+) \\
\hline 14 & 16,7 & 10 & 6,7 & Positive (+) \\
\hline 15 & 30 & 20 & 10,0 & Positive (+) \\
\hline
\end{tabular}

Based on Table 5, it can be seen that there were two types of changes that occurred after students participated in Interactive Conceptual Instruction (ICI) learning with computer simulations, namely the type of positive change (+) and the type of not experiencing change or no change $(0)$. The positive change type indicated fewer misconceptions from pretest to posttest. This type of change occurred in MC1, MC2, MC3, MC4, MC5, MC6, MC7, MC8, MC9, MC10, MC11, MC13, MC14, MC15. The biggest change to this type was on the MC8. MC8 was reduced from $53.5 \%$ to $30 \%$ resulting in a difference of $23.3 \%$. According to the relationship between momentum and impulse, if a soft object collides with another object, the law of conservation of momentum does not apply.

Although most types of change were positive, it turned out that there were still types of changes that did not change. It was MC12 regarding the concept of partially elastic collisions. It was said that the total kinetic energy possessed by objects before and after the collision was the same regardless of any changes in kinetic energy to thermal energy and sound energy. This indicated that the application of Interactive Conceptual Instruction (ICI) with computer simulations could not fully decrease student misconceptions. Misconceptions could not be changed in a short time. This was in line with the findings of Achmad Samsudin et al. (2015) and Fratiwi et al. (2017), which stated that misconceptions that occurred in students were difficult to change in a short time because misconceptions were embedded in students' thinking.

Regarding this, Samsudin et al. (2016) stated that misconceptions in students were difficult to change because of the limitations of researchers in controlling psychological problems such as student thinking, group collaboration, and student motivation. Meanwhile, some solutions can be used, such as media, learning models, and experiments.

Furthermore, the criteria for changing students' conceptions can be seen based on 
the pretest and posttest results. The criteria for changing the conception can be grouped into three categories, namely Acceptable Change (AC), Not Acceptable (NA), and
Not Change (NCh). The criteria for changing students' conceptions are shown in Figure 8 as follows.

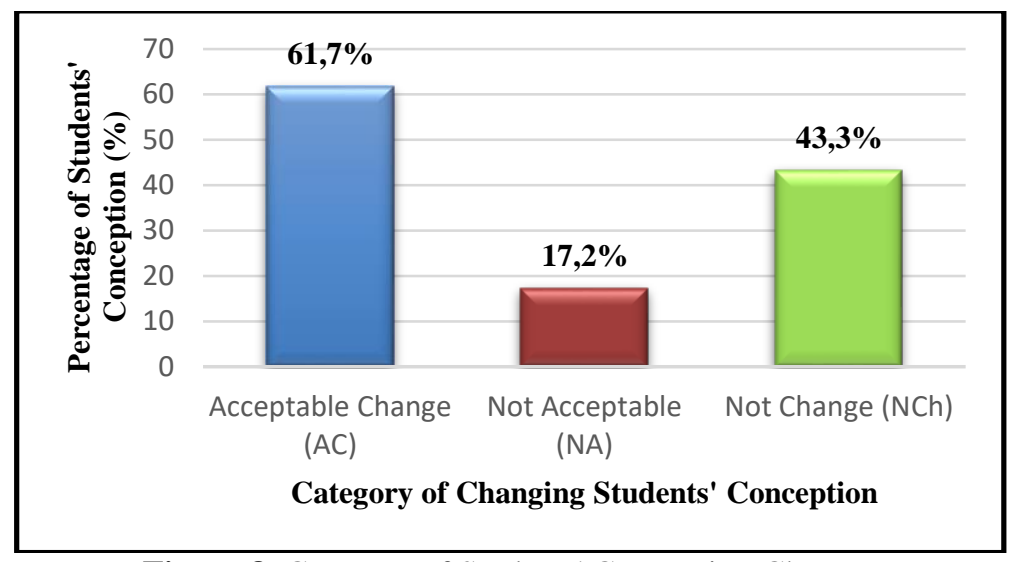

Figure 8. Category of Students' Conception Changes

Based on the explanation above, there were many Not Acceptable (NA) and Not Change (NCh) occurrences. This indicated that the application of Interactive Conceptual Instruction (ICI) learning with computer simulations could not completely change students' misconceptions on momentum and impulse material. Changing students' misconceptions that were not maximum could occur because students paid less attention to teacher explanations and directions during the learning process, were not used to using computer simulations, and many students were passive during the learning process.

Based on the results obtained, the N-gain interpretation score showed that the application of Interactive Conceptual Instruction (ICI) with computer simulations could change students' misconceptions on momentum and impulse material. This was supported by the type of change in students' misconceptions on momentum and impulse material which tended to be positive $(+)$. The category of changing student conceptions was Acceptable Change (AC), which meant students had an increased understanding of concepts. Supported by several research results, it can be said that the application of Interactive Conceptual Instruction (ICI) learning with computer simulations can change students' misconceptions on momentum and impulse material (Samsudin et al., 2016; Samsudin et al., 2017; Savinainen, 2005).

Explanations related to students' misconceptions for each question item (Q1 Q15) were described in the following description. Q1 and Q2 discussed momentum. In Q1, as many as $20 \%$ of students experienced a misconception that if an object had a large mass, then the object had a large momentum without being influenced by the object's velocity (MC1), while in Q2, 30\% of students experienced a misconception that momentum was only affected by the object's velocity, the smaller the object's velocity, the smaller the object's momentum regardless of the object's mass (MC2). In the Conceptual Focus stage, a video was shown of two marbles having different masses moving along a starchy road, as shown in Figure 9.

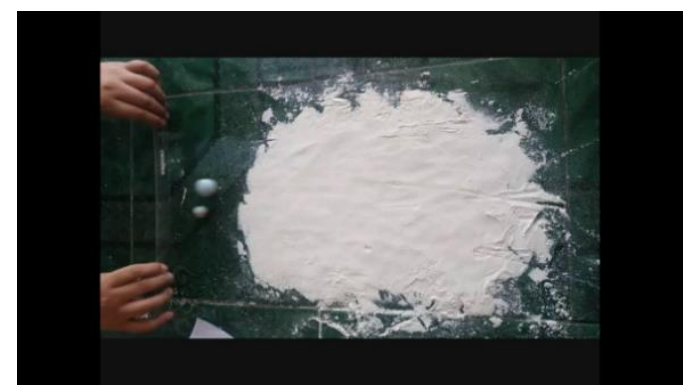

Figure 9. Scene from the Displayed Video 
Before the video was shown, students were asked to make predictions, "which marble will stop faster? What is the reason?". Students began to discuss in groups and then expressed their opinions. After the students had submitted predictions for the first video, another video was shown about a ball with the same mass moving at different speeds. Students were again asked to predict which ball would stop faster. After the video was shown, students could conclude that the object's momentum depends on the object's mass and velocity. The post-test found that misconceptions in Q1 were reduced by $16.7 \%$, and in Q2 were reduced by $20 \%$. The posttest results also showed that in Q1, the students 'concept of sound understanding increased to $56 \%$ (17 students), while in Q2, the students' concept of sound understanding increased to $36.7 \%$ (11 students).

Furthermore, Q3 still discussed momentum. The pretest results stated that $23.3 \%$ of students believed that momentum was not a vector quantity (MC3). This was because there were still students who did not know that velocity had a magnitude and direction. Efforts made to minimize this misconception were in stage 2 of the Interactive Conceptual Instruction (ICI), students were guided to find information about momentum and create concept maps. In stage 3, namely research-based materials, the computer simulation used could show that momentum was a vector quantity. The posttest results showed that students' misconceptions were reduced by $13.3 \%$, while the criteria for sound understanding had the largest percentage than other conception criteria, which was $46.7 \%$ (14 students). $46.7 \%$ of students believed that momentum was a vector quantity. It had both a magnitude and a direction.

Q4 and Q5 discussed impulses. The pretest results showed that in Q4, 16.7\% of students experienced a misconception believing that the speed of an object affected the magnitude of the impulse (MC4). Whereas for Q5, as many as $16.7 \%$ of students experienced a misconception in producing a large force, it took a long-time interval (force is directly proportional to the time interval (MC5). During the learning process, especially in stage 2 in Interactive Conceptual Instruction (ICI), namely the use of text, students were guided to find information about impulses and create mind maps. In making the mind map, students would understand the relationship between force and time interval. In the next stage, students could also find out the application of impulses in everyday life. The posttest results showed that the students' misconceptions in Q4 and Q5 were reduced to $10 \%$, respectively, which meant that only three students experienced misconceptions. Based on the posttest results, it was also found that the largest percentage was the partial understanding criteria in Q4, as many as $56.7 \%$, and in Q5 for about $53.3 \%$.

In comparison, sound understanding in Q4 and Q5 was 30\%, respectively. Students who had sound understanding in Q4 believed that the impulse was only affected by the time interval and the force produced. In Q5, students believed that it took a very small contact time (force is inversely proportional to the time interval).

Q6 and Q7 discussed the relationship between momentum and impulse. Based on the pretest results, Q6 experienced a misconception of $26.7 \%$, where students believed that impulses were momentum (MC6). In Q7, students experienced a misconception of $26.7 \%$, and students believed that the change in momentum was inversely proportional to force (MC7). Efforts were made to minimize misconceptions by showing the relationship between momentum and impulse in everyday life. One example was two people who were playing baseball. Playing baseball was not possible to be implemented in the class; therefore, utilizing computer simulations was appropriate. In the computer simulation used in this study, there were five quantities, namely mass, force, time interval, initial velocity, and 
final velocity. Students could input the values for mass, force, time interval, and velocity, while the object's final velocity would appear when the computer simulation started. Student worksheets also assisted the use of computer simulations. After students got the final velocity of objects, students were guided to fill in the worksheet. The worksheet filled in by students could guide students to find the correct scientific concept through several questions that linked the concepts of momentum and impulse. The pretest results showed that the misconceptions in Q6 and Q7 were reduced by $13.3 \%$, respectively. As many as $53.3 \%$ (16 students) had sound understanding in Q6, while in Q7 there were $16.7 \%$ (5 students) had a sound understanding. Students who experienced sound understanding or understood the concept in Q6 believed that impulses were a change in momentum, while in Q7, students believed that changes in momentum were proportional to force.

Q8 and Q9 discussed the Law of Momentum Conservation. Q8 and Q9 had the same questions, but the examples being used distinguished these two questions. The pretest results showed a misconception in Q8 of $53.3 \%$ and Q9 of $33.3 \%$. Students who experienced misconceptions in Q8 believed that if a soft object collided with another object, then the Law of Momentum Conservation did not apply (MC8). In Q9, students who experienced misconceptions believed that the Law of Momentum Conservation applied to objects that experienced partially elastic collisions. Efforts to reduce misconceptions on the Law of Momentum Conservation were to take advantage of stages 2 and 3 of the Interactive Conceptual Instruction (ICI), namely text and research-based material. At the next stage, students looked for information about the Law of Momentum Conservation and made a mind map.

Then to prove the information that had been obtained at the use of text stage, students conducted experiments using computer simulations and student worksheets at the research-based material stage. In the next stage, students would get information that the Law of Conservation of Momentum applied to each type of collision. Then students proved it by using a collision computer simulation. Students were asked to input grades based on directions from the student worksheet then students would get the data needed to fill in the student worksheet. The students' worksheet's directions and questions would guide to prove that the Law of Momentum Conservation meant that the initial momentum and final momentum of the object were the same, and the Law of Momentum Conservation applied to each type of collision. After the posttest was carried out, the results showed that in Q8, students who experienced misconceptions decreased to $30 \%$, and sound understanding was $3.3 \%$ (1 student). Students who had sound understanding criteria believed that the Law of Momentum Conservation applied to every type of collision object. Q8 had the largest percentage of misconceptions after implementing Interactive Conceptual Instruction (ICI) with computer simulations. This was because the simulation used in the study only utilized a ball as an example of an object, while in Q8, the objects used were various. There were still many students who misunderstood the application of the Law of Momentum Conservation in everyday life. In the Q9 posttest results, misconceptions were reduced to $13.3 \%$, and the criteria for sound understanding increased to $3 \%$ (1 student). Students who had sound understanding criteria believe that the Law of Momentum Conservation applied to all types of collisions (perfectly elastic and partially elastic).

Meanwhile, Q10 and Q11 discussed the perfectly elastic collision. In Q10, as many as $20 \%$ of students experienced a misconception that was when two objects with the same mass collided, there would be a partially elastic collision (MC10), while in 
Q11, as many as $13.3 \%$ of students experience a misconception, namely that the total momentum of the object was greater before the collision than after the collision (MC11). As explained in the previous paragraph, students looked for information first, then they made mind maps and proved the information through the computer simulations. In computer simulation, students inputted data, namely the mass, velocity, and elasticity of objects. Before the simulation began, students would get the initial momentum of the ball. Students would obtain data on the final velocity and final momentum of objects when the simulation was started. After that, the students redid the lab with different initial masses and velocities. After obtaining several different data, students were asked to compare these data. At the end of the practicum, students could conclude that mass did not affect the type of collision that occurred but the initial and final velocity of the object, which determined the type of collision that occurred. Students also concluded that the total momentum of the object before and after the collision was the same. Therefore, students' misconceptions in Q10 were reduced to $13.3 \%$, while in $\mathrm{Q} 11$, it was reduced to $10 \%$. The criteria for sound understanding experienced a very small percentage increase, which was in Q10 to $6.7 \%$ and in Q11 to $3.3 \%$. In comparison, the criteria for partial understanding experienced a significant increase in percentage to $73.3 \%$ for Q10 and $83.3 \%$ for Q11.

Furthermore, Q12 and Q13 discussed partially elastic collisions. In Q12, as many as $20 \%$ of students experienced a misconception. Before and after the collision, the total kinetic energy possessed by the object was the same without paying attention to the change in kinetic energy into thermal and sound energy (MC12). In comparison, in Q13, as many as $20 \%$ of students experienced a misconception. The students believed that the difference in mass of two objects during the collision was a partially elastic collision regardless of the collision restitution coefficient generated after the collision (MC13). At the materialbased research stage, students did practicum using computer simulations. The data obtained showed the value of the initial and final kinetic energy of the object, the initial and final momentum of the object, and the initial velocity and velocity of the object. All of these data were entered into the observation table so that students could compare each data obtained. Students could conclude that the total kinetic energy after the collision was smaller than before the collision based on the table. The partially elastic collision was indicated by the collision restitution coefficient produced after the collision, namely $1>0>1$. In Q12, there was no change in misconceptions. There were students whose misconceptions change to other criteria, and there were students who initially had the criteria for a sound understanding and partial understanding but later experienced a misconception. In Q13, misconceptions were reduced to $6.7 \%$, and there were criteria for sound understanding to $23.3 \%$.

Q14 and Q15 discussed non-elastic collisions. In Q14, $16.7 \%$ of students experienced a misconception about whether two objects had speed, and the other was static when colliding. The collision is not elastic (MC14), while in Q15, as many as $30 \%$ of students experienced a misconception, namely two balls that fused after the collision had a greater total kinetic energy than before the collision (MC15). Through Interactive Conceptual Instruction (ICI) with computer simulations, students were guided to find the correct concept so that misconceptions that occurred could be reduced. The data obtained by students on these two indicators were the same as Q10 and Q11, where students obtained information and could conclude based on information obtained through computer simulations. After implementing Interactive Conceptual Instruction (ICI) with computer simulations, students' misconceptions in 
Q14 were reduced to $10 \%$, and in Q15, it was reduced to $20 \%$. The criteria for sound understanding increased to $46.7 \%$ in Q14, and in Q15, it increased slightly to $23.3 \%$.

Q10 - Q15 as a whole discussed the total kinetic energy and the total momentum of the object before and after the collision. Many students mistakenly distinguished the characteristics of each type of collision. The students thought that what distinguished the types of collisions was the mass and velocity of the object. This was fatal and could lead to misconceptions. Overall, in Q10 - Q15, after implementing Interactive Conceptual Instruction (ICI) with computer simulation, students could find out the point of understanding error in distinguishing each type of collision.

\section{CONCLUSION AND SUGGESTION}

Based on the research results regarding the investigation of students 'misconceptions on momentum and impulses after applying Interactive Conceptual Instruction (ICI) with computer simulations, it was concluded that students' misconceptions before being given treatment were bigger than after being given treatment. This could be seen from a decrease in misconceptions by $11.6 \%$ after implementing Interactive Conceptual Instruction (ICI) with computer simulations. This can be a reference for further research to implement Interactive Conceptual Instruction (ICI) with computer simulations on other physics concepts.

\section{ACKNOWLEDGMENT}

This work was financially supported by "Hibah Penelitian Terapan Unggulan Perguruan Tinggi" Research Grants in the fiscal year 2020, KEMENRISTEKDIKTI Republic of Indonesia.

\section{AUTHOR CONTRIBUTIONS}

AD wrote the background of the problem. IS and AS develop research instruments and designs. GY analyzed the data. AS presents data in tables and displays figures. AD and AS compile research results and abstracts.

\section{REFERENCES}

Adimayuda, R., Aminudin, A. H., Kaniawati, I., Suhendi, E., \& Samsudin, A. (2020). A multitier openended momentum and impulse (MOMI) instrument: Developing and assessing quality of conception of 11th grade sundanese students with rasch analysis. International Journal of Scientific and Technology Research, 9(2), 4799-4804.

Akmam, A., Anshari, R., Amir, H., Jalinus, N., \& Amran, A. (2018). Influence of learning strategy of cognitive conflict on student misconception in computational physics course. IOP Conference Series: Materials Science and Engineering, 335(1). https://doi.org/10.1088/1757899X/335/1/012074

Amalia, S. a., Suhendi, E., Kaniawati, I., Samsudin, a., Fratiwi, N. J., Hidayat, S. R., Zulfikar, a., Sholihat, F. N., Jubaedah, D. S., Setyadin, a. H., Purwanto, M. G., Muhaimin, M. H., Bhakti, S. S., \& Afif, N. F. (2019). Diagnosis of student's misconception on momentum and impulse trough inquiry learning with computer simulation (ILCS). Journal of Physics: Conference Series, 1204(1). https://doi.org/10.1088/17426596/1204/1/012073

Amelia, R., Rofiki, I., TORTOP, H. S., \& ABAH, J. A. (2020). Pre-service teachers' scientific explanation with escaffolding in blended learning. Jurnal Ilmiah Pendidikan Fisika Al-Biruni, 9(1), 33-40. https://doi.org/10.24042/jipfalbiruni.v9 i1.5091

Aminudin, A. H., Kaniawati, I., Suhendi, E., Samsudin, A., Coştu, B., \& Adimayuda, R. (2019). Rasch analysis of multitier open-ended light-wave instrument (MOLWI): Developing and 
assessing second-years sundanesescholars alternative conceptions. Journal for the Education of Gifted Young Scientists, 7(3), 607-629. https://doi.org/10.17478/jegys.574524

Astiti, D. T., Ibrahim, M., \& Hariyono, E. (2020). Application of POE (predictobserve-explain) learning strategies to reduce students' misconceptions in science subjects in elementary school. International Journal of Innovative Science and Research Technology, 5(7), 437-445. https://doi.org/10.38124/ijisrt20jul478

Creswell, J. W. (2014). Research design qualitative, and mixed methods approaches 4th ed (K. Vicki, Ed.). SAGE Publications Inc.

Fratiwi, N. J., Kaniawati, I., Suhendi, E., Suyana, I., \& Samsudin, A. (2017). The transformation of two-tier test into four-tier test on Newton's laws concepts. AIP Conference Proceedings, 1848.

https://doi.org/10.1063/1.4983967

Fratiwi, N. J., Samsudin, a., \& Costu, B. (2018). Enhancing K-10 students' conceptions through computer simulations-aided $\mathrm{PDEODE}^{*} \mathrm{E}$ (CSPDEODE*E) on Newton's Laws. Jurnal Pendidikan IPA Indonesia, 7(2), 214-223.

https://doi.org/10.15294/jpii.v7i2.1422 9

Fratiwi, N. J., Samsudin, A., Ramalis, T. R., \& Costu, B. (2020). Changing students' conceptions of Newton's second law through express-refute-investigateclarify (ERIC) text. Universal Journal of Educational Research, 8(6), 27012709.

https://doi.org/10.13189/ujer.2020.080 655

Gersten, R., Fuchs, L. S., Compton, D., Coyne, M., Greenwood, C., \& Innocenti, M. S. (2005). Quality indicators for group experimental and quasi-experimental research in special education. Exceptional Children,71(2),
149-164.

https://doi.org/10.1177/0014402905071 00202

Hikmat,Tayubi, Y. R., Purwana, U., \& Andi Suhandi. (2014). Strategi konflik kognitif berbantuan media simulasi virtual dalam pembelajaran fisika berorientasi pengubahan konseptual untuk meningkatkan pemahaman konsep dan menurunkan kuantitas siswa yang miskonsepsi. Prosiding Pertemuan Ilmiah XXVIII HFI Jateng, 342-347.

Irwansyah, I., Sukarmin, S., \& Harjana, H. (2018). Development of three-tier diagnostics instruments on students misconception test in fluid concept. Jurnal Ilmiah Pendidikan Fisika AlBiruni, $\quad 7(2), \quad 207$. https://doi.org/10.24042/jipfalbiruni.v7 i2.2703

Kaniawati, I., Fratiwi, N. J., Danawan, A., Suyana, I., Samsudin, A., \& Suhendi, E. (2019). Analyzing students' misconceptions about Newton's Laws through Four-Tier Newtonian Test (FTNT). Journal of Turkish Science Education, 16(1), 110-122. https://doi.org/10.12973/tused.10269a

Kaniawati, I., Samsudin, A., Hasopa, Y., Sutrisno, A. D., \& Suhendi, E. (2016). The Influence of using momentum and impulse computer simulation to senior high school students' concept mastery. Journal of Physics: Conference Series, 739(1). https://doi.org/10.1088/17426596/739/1/012060

Kurniawan, Y., Muliyani, R., \& Nassim, S. (2019). Digital story conceptual change oriented (DSCC) to reduce students' misconceptions in physics. Jurnal Ilmiah Pendidikan Fisika Al-Biruni, 8(2), 207-216. https://doi.org/10.24042/jipfalbiruni.v0 i0.4596

Ling, T. W. (2017). Fostering understanding and reducing misconceptions about image formation by a plane mirror using constructivist-based hands-on 
activities. In overcoming students' misconceptions in science. Springer Singapore, 203-222. https://doi.org/10.1007/978-981-103437-4_11.

Nasrudin, H., \& Azizah, U. (2020). Overcoming student's misconception through implementation of metacognitive skills-based instructional materials in energetics. Jurnal Pendidikan IPA Indonesia, 9(1), 125134.

https://doi.org/10.15294/jpii.v9i1.2163 0

Patriot, E., Suhandi, A., \& Chandra, D. (2017). Effect of implementation interactive conceptual instruction with multi representation approach to improve levels of understanding on work and energysubject matter. http://seminar.uny.ac.id/icriems/sites/se minar.uny.ac.id.icriems/files/prosiding 2017/PE04_evelina.pdf

Rismawati, R., Sarwanto, S., \& Saputro, B. (2019). Project-based (PjBL) and guided inquiry learning: Students' response to rectilinear and circular motion phenomena. Jurnal Ilmiah Pendidikan Fisika Al-Biruni, 8(2), 187-196.

https://doi.org/10.24042/jipfalbiruni.v0 i 0.4422

Rogers, J., \& Révész, A. (2020). Experimental and quasi-experimental designs. In The Routledge Handbook of Research Methods in Applied Linguistics (pp. 133-143). https://doi.org/10.4324/9780367824471 $-12$

Samsudin, A., Aminudin, A. H., \& Fratiwi, N. J. (2021). Measuring students' conceptions of light waves: A survey in Central Java measuring students' conceptions of light waves: A survey in Central Java.Journal of Physics: Conference Series, 1796(1) https://doi.org/10.1088/17426596/1796/1/012124
Samsudin, A., Fratiwi, N., Amin, N., Wiendartun, Supriyatman, Wibowo, F., Faizin, M., \& Costu, B. (2018). Improving students' conceptions on fluid dynamics through peer teaching model with PDEODE (PTMPDEODE). Journal of Physics: Conference Series, 1013(1). https://doi.org/10.1088/17426596/1013/1/012040

Samsudin, A., Fratiwi, N. J., Ramalis, T. R., Aminudin, A. H., Costu, B., \& Nurtanto, M. (2020). Using rasch analysis to develop multirepresentation of tier instrument on newton's law (motion). International Journal of Psychosocial Rehabilitation, 24(6), 8542-8556. https://doi.org/10.37200/IJPR/V24I6/P R260865

Samsudin, A., Liliawati, W., Sutrisno, A. D., Suhendi, E., \& Kaniawati, I. (2015). The use of computer simulation in cooperative learning to minimize students' misconceptions of momentum and impulse. Proceedings of the 2014 International Conference on Advances in Education Technology, 11 . https://doi.org/10.2991/icaet14.2014.16

Samsudin, A., Suhandi, A., Rusdiana, D., \& Kaniawati, I. (2016). Preliminary design of ICI-based multimedia for reconceptualizing electric conceptions at universitas pendidikan indonesia. Journal of Physics: Conference Series, 739(1). https://doi.org/10.1088/17426596/739/1/012006

Samsudin, A., Suhandi, A., Rusdiana, D., Kaniawati, I., \& Coştu, B. (2016). Investigating the effectiveness of an active learning based-interactive conceptual instruction (ALBICI) on electric field concept. Asia-Pacific Forum on Science Learning and Teaching, 17(1), 1-41.

Samsudin, A., Suhandi, A., Rusdiana, D., Kaniawati, I., \& Coştu, B. (2017). Promoting conceptual understanding 
on magnetic field concept through interactive conceptual instruction (ICI) with PDEODE $* \mathrm{E}$ tasks. Advanced Science Letters, 23(2), 1205-1209. https://doi.org/10.1166/as1.2017.7539

Santoso, H. B., Batuparan, A. K., Isal, R. Y. K., \& Goodridge, W. H. (2018). The development of a learning dashboard for lecturers: A case study on a studentcentered e-learning environment. Journal of Educators Online, 15(1). https://doi.org/10.9743/JEO.2018.1.1

Savinainen, A. (2005). High school students' conceptual coherence of qualitative knowledge in the case of the force concept. Nordic Studies in Science Education, 1(2), 100. https://doi.org/10.5617/nordina.501

Savinainen, A., \& Scott, P. (2002). Using the force concept inventory to monitor student learning and to plan teaching. Physics Education, 37(1), 53-58. https://doi.org/10.1088/00319120/37/1/307

Soeharto, Csapó, B., Sarimanah, E., Dewi, F. I., \& Sabri, T. (2019). A review of students' common misconceptions in science and their diagnostic assessment tools. Jurnal Pendidikan IPA Indonesia, $\quad 8(2), \quad 247-266$. https://doi.org/10.15294/jpii.v8i2.1864 9

Tompo, B., Ahmad, A., \& Muris, M. (2016). The development of discovery-inquiry learning model to reduce the science misconceptions of junior high school students. International Journal of Environmental and Science Education, 11(12), 5676-5686.

Tumanggor, A. M. R., Supahar, S., Ringo, E. S., \& Harliadi, M. D. (2020). Detecting students' misconception in simple harmonic motion concepts using four-tier diagnostic test instruments. Jurnal Ilmiah Pendidikan Fisika AlBiruni, 9(1), 21-31. https://doi.org/10.24042/jipfalbiruni.v9 i1.4571

Widyawati, E. (2019). Learning development of cooperative model based phet media to reduce potential misconceptions in dynamic electric matter for tenth grade in state senior high school. International Journal of Innovative Science and Research Technology,4(9), 546-557.

Zulfikar, A., Saepuzaman, D., Novia, H., Setyadin, A. H., Jubaedah, D. S., Sholihat, F. N., Muhaemin, M. H., Afif, N. F., Fratiwi, N. J., Bhakti, S. S., Amalia, S. A., Hidayat, S. R., Nursani, Z., Hermita, N., Costu, B., \& Samsudin, A. (2019). Reducing eleventh-grade students' misconceptions on gravity concept using PDEODE*E-Based conceptual change model. Journal of Physics: Conference Series, 1204(1). https://doi.org/10.1088/17426596/1204/1/012026 